http://dx.doi.org/10.12775/szhf.2014.032

\author{
EMMANUEL LAJUS
}

\title{
Aion i osobliwości wydarzenia
}

\section{„1.9.96}

Pierwszy września!

1939: jest słoneczny, ciepły ranek. Podwórze przed domkiem wujka w Pawłowie, gdzie jesteśmy na wakacjach. Na leżaku siedzi pochylony dziadek. Jest sparaliżowany, wokół głowy ma świeżą szramę po operacji. Pamiętam go: był wysoki, szczupły, miał pociągłą, chudą twarz, porośniętą szczeciną. Dziadek laską wskazuje niebo - w górze, wysoko, w oceanie błękitu kilka srebrnych punktów. Są ledwie widoczne. Dolatuje mnie odległe brzęczenie, warkot, pulsujący szum silników. Pierwszy raz w życiu słyszę taki dźwięk. Nigdy jeszcze nie widziałem samolotu, nie słyszałem jego odgłosu.

- Dzieci! - woła dziadek mierząc szpicem laski w samoloty - zapamiętajcie ten dzień! Zapamiętajcie! - powtarza wygrażając laską nie wiem komu nam? samolotom? światu?"1

Kiedy Kapuściński zastanawia się, komu dziadek wygraża, czujemy, że to pytanie nie dotyczy wyłącznie stanu wewnętrznego, zamiarów dziadka. Najwyraźniej stawiając je, autor chciałby dodać coś do elementów opisywanej sytuacji, rozumianych jako fakty. Jego pytania odnoszą się jednak do całej sceny i brzmią pod każdym zdaniem opisu, są znakiem zdziwienia wobec następujących po sobie zdarzeń, wyrażają przeczucie sensu, które przenika cały tekst. Dlatego ta krótka opowieść wydaje się dobrym wprowadzeniem do pytania o wydarzenie.

\footnotetext{
${ }^{1}$ R. Kapuściński, Lapidaria, Warszawa 2008, s. 374.
} 
Czego szukamy, gdy zadajemy pytanie: „Co się stało?”, gdy pytamy o sens tego, co się wydarzyło? Według Deleuze'a możemy odrzucić trzy możliwe odpowiedzi. Po pierwsze, nie zależy nam na możliwie najwierniejszym odtworzeniu sceny. Fakty nie oddają sensu wydarzenia, bo sens przekracza wskazane desygnaty. A może szukamy znaczenia, rozumianego jako związek słowa z powszechnymi czy ogólnymi pojęciami? Ale wtedy scena straci swoją jedyność, swoją wyjątkowość i stanie się tylko jednym spośród wielu elementów zbioru. Odpowiedź na pytanie o sens powinna wydobyć coś, co należy wyłącznie do niej. Poszukiwany sens jest sensem jedyności pewnej chwili. Czy zawiera się on w uczuciach osoby, tutaj Kapuścińskiego? W końcu to pisarz szuka w sobie odpowiedzi, odwołuje się do swojej pamięci, swoich wspomnień, dlatego można by uznać, że sensem tej sceny będzie tutaj przede wszystkim to, co ma sens dla niego. Ale w ten sposób, czy to według Kapuścińskiego, czy Deleuze’a, mijalibyśmy się z istotą wydarzenia.

Istotnie, wydarzenie nie istnieje tylko w nas, w osobach. Ono jest, istnieje też na zewnątrz nas albo raczej granica pomiędzy tym, co jest w nas, i tym, co jest na zewnątrz nas, traci znaczenie. Poszukujemy tego, co rzeczywiście powstało, istniało, a nie tylko sensu, który wydarzenie miało dla nas. Ale gdzie jest wydarzenie, skoro nie jest ani w rzeczach (w stanach rzeczy), ani w znaczeniu słów, które mogą je opisać, ani w osobie, która je odbiera? Gdzie jest 'miejsce' wydarzenia?

Według Kapuścińskiego, żeby przekazać sens wydarzenia, trzeba oddać jego teatrum albo to, co nazywa on "nastrojem”. Teatrum nie redukuje się do elementów sceny, jest trudno uchwytnym i niepodzielnym zbiorem uczuć, przedmiotów, akcji. Nie należy wyłącznie do stanów rzeczy (skoro fakty nic nie mówią) ani do porządku języka (skoro usiłujemy uchwycić to, co rzeczywiście powstało). Sens istnieje pomiędzy, na granicy rzeczy i słów. I to jest miejsce wydarzenia według Deleuze’a.

Pojęcie wydarzenia, rozumiane jako miejsce myślenia, jest centralne w filozofii Deleuze’a, o czym może świadczyć następujący cytat z książki poświęconej Foucaultowi: „myśleć to widzieć i mówić, ale myśleć występuje w pomiędzy, w odstępie czy rozłączeniu widzenia i mówienia. To za każdym razem wynaleźć ich wzajemne przeplatanie się. [...] Myśleć to sprawić, że widzenie dociera do własnej granicy i mówienie do swojej, tak że obydwa są wspólną granicą, która je odnosi jedno do drugiego, rozdzielając je"2.

${ }^{2}$ Por. G. Deleuze, Foucault, przeł. M. Gusin, Wrocław 2004, s. 144-145. W oryginale: „penser, c'est voir et c'est parler, mais penser se fait dans l'entre-deux, dans l'interstice ou la dis- 
Pojęcie wydarzenia zostało przedstawione głównie w Logique du sens. To wydarzenie jest najpierw wstrząsem ${ }^{3}$, który stwarza sens niewyrażalny w sposób wyczerpujący, bo zrodzony nie z samego języka, tylko z wstrząsu, tzn. ze spotkania rzeczy i języka. Wstrząs zdarza się zawsze przy okazji pewnego stanu rzeczy, w pewnym momencie, ale sens powstaje jak chmura wirtualności, wirtualności przedmiotów, stanów rzeczy, podmiotów, z których język może uchwycić tylko część, wirtualności tak samo rzeczywistych, jak same przedmioty, ale w innym wymiarze ${ }^{4}$. Przykładem często przywoływanym przez Deleuzéa jest bitwa ${ }^{5}$, która ewidentnie nie ogranicza się do spostrzeganych przez nas przedmiotów, czynów i osób, lecz zagarnia wiele innych jeszcze, rzeczywistych czy możliwych obiektów i zdarzeń. Najważniejsze jest to, że nad tym, co się dzieje w moim polu percepcji i ponad tym, co spostrzegają inni, unosi się wydarzenie bitwy nadające im nowy sens. O ile bitwa jest wydarzeniem dla mnie, o tyle czyny, których jestem świadkiem, nie są czystymi czynami, lecz zostają przeobrażone przez wir bitwy, wydającej się bytem samodzielnym, nieograniczonym, bezosobowym. Dla tego, kto przeżyje bitwę jako wydarzenie, rzeczy, jakie widzi, są tajemniczym wcieleniem bitwy, żywymi obrazami nawiedzonymi przez nią lub raczej miejscem niepodzielnego wydarzenia rzeczy i języka (Deleuze podkreśla swoistość tego sposobu istnienia, posługując się etymologicznymi znaczeniami czasowników „subsister” = stać pod... i „,insister” = stać w..., żeby go odróżnić od „exister” = stać na zewnątrz).

Wydarzenie składa się z osobliwości, to jest z konkretnych elementów danej sytuacji, które przez to, co się stało, przejęły nowy sens - zostały przeobrażone przez wydarzenie. Wydarzenie nie jest tym, co się dzieje (konkretną

jonction du voir et du parler. C'est chaque fois inventer l'entrelacement [...] Penser c'est faire que voir atteigne à sa limite propre, et parler à la sienne, si bien que les deux soient la limite commune qui les rapporte l'un à l'autre en les séparant", G. Deleuze, Foucault, Paris 2004, s. 93.

${ }^{3}$ Określenie G. Marcela, którego intuicje są czasami bliskie filozofii Deleuze’a. Por. G. Marcel, Od sprzeciwu do wezwania, przeł. S. Ławicki, Warszawa 1965, s. 87.

${ }^{4}$ Por. G. Deleuze, Różnica i powtórzenie, przeł. B. Banasiak i K. Matuszewski, Warszawa 1997, s. 294: „Wirtualność należałoby nawet definiować jako nieodłączną część przedmiotu rzeczywistego - jakby przedmiot tkwił jedną częścią w wirtualności i był w niej zanurzony niczym w wymiarze obiektywnym”; Différence et répétition, Paris 1968, s. 269: „Le virtuel doit même être défini comme une stricte partie de l'objet réel - comme si lobjet avait une de ses parties dans le virtuel, et y plongeait comme dans une dimension objective". Za Bergsonem, Deleuze przeciwstawia to, co wirtualne, $\mathrm{z}$ jednej strony temu, co realne (fizyczne, określone, ograniczone) i z drugiej strony temu, co możliwe (abstrakcyjne, intelektualne).

${ }^{5}$ G. Deleuze, Logique du sens, Paris 1969, s. 122. 
sytuacją), ale czymś w tym, co się dzieje, co przywraca sposoby bycia i czucia. W sferze faktów żołnierz umiera, pewne przedmioty stoją, widać pewne krajobrazy: jednak wydarzenie przekształca ich byt, sprawiając, że stają się one jego punktami intensywności, „anonimowymi i nomadycznymi”. Przez wydarzenie i przez kontakt z sobą jednostkowe elementy stają się czymś innym: krajobraz staje się przez bitwę pewnym, jedynym przeznaczeniem żołnierza, jakby przejął na swój sposób jego byt i jednocześnie żołnierz staje się tym krajobrazem, nawiedzonym przez przeznaczenie. Osobliwości są elementami sytuacji, które stają się czym innym, są miejscem procesów stawania się. Stawanie się nie zachodzi tylko w tym, co z niego spostrzegamy (np. krajobraz, który staje się żołnierzem), jest przede wszystkim tym, co przychodzi, przenika z jednej rzeczy do drugiej: potencjalną energią sensu, przepływem. Styczność między żołnierzem a krajobrazem wywołuje przepływ, który ich zmienia, ale nie można go nazwać przeznaczeniem, nie pamiętając, że nie jest całkowicie wyrażalny, bo jest siłą.

Skoro wydarzenie prowadzi rzeczy i język do własnej granicy i jest jakby jedynym żywym punktem styczności między nimi, wydaje się zrozumiałe, że Deleuze uważa je za źródło języka, metafizyczny moment, w którym dźwięk nabiera sensu, wydobywa z siebie sens umożliwiający zaistnienie wyobrażeń, znaczeń, sądów, itd. Wydarzenie jest najpierw wstrząsem, wstrząsem pojawienia się sensu wśród rzeczy, z rzeczami. W wydarzeniu da się usłyszeć, jakby w tle, szmer, pomruk pierwotnego stworzenia sensu, wyrwania się sensu $\mathrm{z}$ chaosu, którego ślady nosi jeszcze w sobie. Ten pomruk jest być może najbardziej odczuwalny w wypowiedziach schizofrenika, jak Antonin Artaud, w jego „słowach-tchnieniach” czy „słowach-krzykach”. Wstrząs i szmer towarzyszą każdemu wydarzeniu, co stwarza między nimi rezonanse, tak że jedno Wydarzenie wydarza się w każdym szczególnym wydarzeniu?

Wydarzenie czy sens, które nie jest zrodzone ani z samych rzeczy, ani z wiecznych, nieruchomych znaczeń języka, chociaż nie istnieje bez nich, musi przeto egzystować w innej czasowości. Jaki rodzaj czasu jest dla niego właściwy? Nie ten, który przypisujemy znaczeniom i ich określonym definicjom, gdyż wydają się one należeć do wieczności, podobnej do wieczności platońskich idei. O ile ona wyklucza ruch nie może być czasem wydarzenia, skoro wydarzenie objawia wirtualności, jest nimi. Wstrząs wydarzenia zmusza myśl do stwarzania, do wynalezienia i zarazem do odkrycia coraz no-

6 Tamże, s. 125.

7 Tamże, s. 179, 208-211. 
wych wirtualności. Słowo „wynalezienie” znaczy, że wirtualności nie istnieją w sobie, nieruchomo, poza myślą (na sposób platońskich idei, które mędrzec może kontemplować), a „odkrycie” wyraża bezosobowy, niezależny aspekt wirtualności, o ile wskazują na horyzoncie na własną zasadę („zasada hegemoniczna"8). Uczestnicząc w wydarzeniu, nie rozpoznaję ani nie wynajduję tej zasady; to ona zmusza mnie do wyjścia z granic podmiotowości, do tego, żebym był w świecie, $\mathrm{z}$ rzeczami, $\mathrm{z}$ intensywnościami, które nie są tylko 'ze mnie', ale ze świata albo ze mnie jako części świata, a nie podmiotu.

Jeśli chodzi o rzeczy, o stany rzeczy, należą do czasu, który mierzy ruch, do regularnego czasu następujących po sobie empirycznych stanów rzeczy. To Chronos, symbolizowany przez koło, dlatego, że jest miejscem powrotu tego Samego, według wiecznych praw. Rzeczywiście istnieje w nim, trwa, tylko czas teraźniejszy, czasy przeszły i przyszły wskazują jedynie na różnice między czasami teraźniejszymi. Te trwania są zmienne, mogą być dłuższe i krótsze, zależnie od świadomości, która je obejmuje (np. kiedy rozważam scenę jako jedną całość, jest ona dla mnie teraźniejsza, nawet gdy składa się z wielu akcji). Idealnie Bóg może obejmować wszystkie stany rzeczy w jednym czasie teraźniejszym ${ }^{9}$.

Ale widzieliśmy, że wydarzenie, mimo iż powstaje w pewnych empirycznych stanach rzeczy, w pewnym konkretnym momencie Chronosa, przekracza go i należy do innego wymiaru, do innej czasowości, którą Deleuze nazywa za stoikami Aionem. W tym czasie chwile nie różnią się czasowo, nie ulegają wiecznej mierze Chronosa, która każe im regularnie następować jedna po drugiej. Chwile są wydarzeniami i nie znają miary, dlatego łamią koło i stwarzają linię bez kresu, linię potencjalnego rozwijania wirtualności. W Logique du sens czytamy: „lévénement implique quelque chose d'excessif par rapport à son effectuation, quelque chose qui bouleverse les mondes [...] et les rend à la profondeur du fond qui les travaille et les dissout” („wydarzenie implikuje coś nadmiernego w stosunku do swojej realizacji, coś, co wywraca światy [...] i oddaje je głębokości głębi, która je ugina i rozpuszcza") ${ }^{10}$. O ile Chronos jest fizycznym i umiarkowanym czasem rzeczywistych ciał, o tyle Aion jest niecielesnym i nieumiarkowanym czasem wirtualnych sensów. Te sensy wynurzają się z chaosu, z czego czerpią wirtualności, intensywności jeszcze nie uporządkowane przez czas i język.

\footnotetext{
8 Tamże, s. 172.

9 Tamże, s. 190-192.

${ }^{10}$ Tamże, s. 196, przekł. własny E. L. (tekst powstał przed publikacją polskiego przekładu).
} 
Przejście między jednym a drugim czasem można znaleźć w paradoksie Zenona: według niego każda chwila może być podzielona na krótsze chwile, i tak w nieskończoność, aż nie będzie chwili obecnej i pozostaną tylko chwile przeszłe i przyszłe. Deleuze zachowuje to pojęcie czasu bez teraźniejszości, bo przystaje ono do jego pojęcia wydarzenia, które nigdy nie jest obecne, empirycznie zrealizowane, ale jest wstrząsem wirtualności.

Jak zrozumieć, że wydarzenie jest zawsze przeszłe (i wtedy zapytamy: „Co się stało?”) i zarazem zawsze przyszłe (zapytamy wówczas: „Co się stanie?"). Początek odpowiedzi Deleuze’a można znaleźć w następującym cytacie z Logique du sens: „Lévénement n’est pas ce qui arrive (accident), il est dans ce qui arrive le pur exprimé qui nous fait signe et nous attend” („wydarzenie nie jest tym, co się dzieje [przypadkiem], jest w tym, co nadchodzi, czystym wyrażonym, które nam daje znak i czeka na nas") ${ }^{11}$. O ile więc wydarzenie „nam daje znak”, myśli zawraca ku „przeszłości” (ale jest to przeszłość idealna, nie fizyczna): znak pojawił się, powstał wstrząs i musimy wracać do niego myślą, na sposób Kierkegaarda, który usiłuje wracać myślą do ważnego wydarzenia, żeby bogacić teraźniejszość. Z drugiej strony, o ile wydarzenie „czeka na nas”, myśl wybiega ku „przyszłości”: wydarzenie wskazuje na idealny punkt pełnego sformułowania swojego sensu, na horyzoncie.

W tym samym rozdziale Deleuze cytuje Joë Bousqueta, francuskiego pisarza, rannego podczas pierwszej wojny światowej: „Moja rana istniała wcześniej niż ja, urodziłem się, żeby ją wcielić"12. Bousquet widzi swoją ranę jako wydarzenie, czyli jako intensywność, wezwanie, z którego stara się wydobyć najwyższy sens i dzięki niemu, ku niemu - wznieść swoje życie.

Na podobnej zasadzie można by zastosować pojęcia wydarzenia i Aion do sceny utrwalonej przez Kapuścińskiego. Sens tego wydarzenia uchwycimy, próbując opisać procesy stawania się, czyli przede wszystkim przepływy, które zachodzą pomiędzy jej elementami. W ten sposób, nie pytając: „czym jest wojna?” tylko: „co się tutaj stało?”, będziemy mieć większą szansę wyrazić konkretne wirtualności wojny jako wydarzenia.

Dla dziadka te samoloty oznaczaja wojnę, ale czujemy, że nie są tylko ozna$k a ̨$ wojny (jak dym jest oznaką ognia), lecz sq̨ wojną, są częścią i zapowiedzią pewnej całości, która już jest wszechobecna. Odtąd wszystko jest schwytane w sieci empirycznych wydarzeń wojennych, zniewalających całą przestrzeń,

\footnotetext{
${ }^{11}$ Tamże, s. 175.

12 Tamże, s. 174.
} 
wszystko nosi znamię wojny, odsyła do niej, ale nie w porządku znaczeń, tyko w skutek ciężkiej choroby już obecnej w całym ciele, mimo że objawy są ledwo widoczne. Ocean błękitu, srebrne punkty, szum silników, ciepło tego poranka, podwórze, nie są tylko „w czasie" wojny, nagle oddzielone od czasu pokoju; one są przejawem („epifanią”) wojny, pachną wojną, która jest w jednej chwili wszędzie i nigdzie, tym bardziej przez to niepokojąca.

Za Deleuzèm można by powiedzieć, że tutaj wojna staje się światem i świat staje się wojną. Ale co przepływa między nimi i nie jest nimi? $\mathrm{Na}$ przykład tych kilka srebrnych punktów na niebie jest wojną, dlatego że są bezosobowe, nieludzkie, nieubłagane, roztapiają się w niebie, które je objawia, jak gdyby całe niebo i świat je wysyłały, były współwinne. Lecz pewna wirtualność tych procesów stawania się, pewien sens przepływu, jaki przebiega pomiędzy, jest $w$ osłupieniu świadomości wydanej ogromnym siłom (ani zupełnie ślepym, ani świadomym), które jej zawdzięczają swój sens, swój byt wewnętrzny. Tu jest zarazem „wola, którą nas obdarza wydarzenie" („la volonté que nous fait l'événement”) ${ }^{13}$ : być może wyzwanie, żebyśmy zostali na tej linii podziału, ze świadomością stałej obecności gróźb ze strony przypadku, chaosu, z bohaterskim wysiłkiem, żeby „rzucić sens w paszczę chaosu", jak mówi poeta. Warkot silników nie jest szumem samej wojny, nie będąc jednocześnie szumem zbliżania się dramatu, możliwego w każdej chwili naszego życia: wściekłość chaosu, który ponownie zwycięża. Czy nasze myśli płynące nad nim wystarczą, żeby nas uratować?

Gdy dziadek mówi: „Zapamiętajcie ten dzień!”, jesteśmy w obliczu drugiego przeobrażenia. To wygląda tak, jakby wydarzenie nagle zmieniało istotę, czy odrealniało byty, które potem nabierają różnych znaczeń przez wzajemne zetknięcie się, związki między nimi, stwarzając nowe przepływy.

Z punktu widzenia naszego i dziadka, pojawienie się wojny wyłoniło z niego i z dzieci nowe postaci. Dziadek jest teraz człowiekiem, który przez swoją przeszłość jest świadomy tego, co się stanie, stoi w tym chwiejnym punkcie między przeszłością a przyszłością (która oznacza prawdopodobnie dla niego śmierć), jak na brzegu przepaści i to z tego punktu mówi do dzieci. Nadejście wojny uwydatnia u nich $\mathrm{z}$ kolei ich dramatyczną bezbronność wobec losu i zarazem ich nieograniczoną (otwartą, czystą) wrażliwość i zdolność nadawania sensu światu.

${ }^{13}$ Tamże, s. 123, 174-176. 
Odtąd można powiedzieć, że dziadek staje się dziećmi w tym sensie, że ich obecność spotęguje w nim poczucie krzywdy spowodowanej przez wojnę i jednocześnie (i jakby przez to właśnie) wskazuje na możliwe zwycięstwo nad nią. Jakie zwycięstwo? Nadanie wojnie sensu wydarzenia, nadanie sensu przeznaczeniu, pojawieniu się przeznaczenia, którym jest ten dzień. Dlatego słowa „zapamiętajcie ten dzień!” są na wysokości wydarzenia: nie ograniczają go do pewnego stanu rzeczy (jak gdyby powiedział na przykład: „Wojna idzie!"), tylko są zwracane do tej czystej wrażliwości dzieci, do ich nieograniczonej zdolności dawania sensu. To te bezbronne dzieci mogą stawić czoła wrogim siłom wojny, przekształcając je w wydarzenie, nadając im sens całym swoim życiem. Tak jakby kruchość, która czyni je bytami prawie nierzeczywistymi, stanowiła o ich sile oporu: oporu powierzchni jeziora odbijającej świat. Innymi słowy można by powiedzieć, że dzięki dzieciom dziadek staje się świadomy tego, co trzeba uratować albo raczej jest tym, staje się tym, kiedy między nim i dziećmi pojawia się przepływ, który ich nieograniczenie przekształca. Toteż można odczuć, że to, co trzeba uratować mówi zarówno dziadek, jak i samo wydarzenie (którego groźbę objawia dzieciom jego postać, wypełniająca rolę précurseur sombre ${ }^{14}$ ). Jak gdyby sama siła przeraziła się chaosem, który zawiera: wydarzenie jako fałda rzeczy i sensów. To dlatego „jego" słowa brzmią „Pamiętajcie!”, bo wydaje się, że to „chce powiedzieć” sam wstrząs jako czysty „il y a” - to jest to, czego wydarzenie żąda przede wszystkim: wracać, być powtarzanym w wiecznym powrocie...

Powaga dziadka, jego groźny rozkaz, który dzieci odnoszą do swojej przyszłości, świadomość wydarzenia, jaką mogą uzyskać dzięki dziadkowi, inicjują w nich proces stawania się dziadkiem, kimś dorosłym. Nie dlatego, że teraz są bardziej podobne do dorosłych (podobieństwo dotyczy „zewnętrza” w szerszym znaczeniu, a nie przepływów); istnieją raczej „cząstki” dorosłych, które mieszają się do cząstek dzieci, żeby stworzyć coś nowego: dzieci nad wiek rozwinięte, świętych idiotów, naiwnych, sięgających korzeni... Swoistą wizję rzeczy, która miesza tutaj w szczególny sposób wrażliwość na wstrząs i świadomość wagi wydarzenia.

Złożona gra Chronosa stanowi tutaj prefigurację Aionu: zaledwie wojna przejawia się, już trzeba ją zapamiętać, przechowywać ją w przyszłości, jak

${ }^{14}$ G. Deleuze, Różnica i powtórzenie, s. 179. „Mroczny zwiastun” poprzedza piorun i określa jego drogę. Deleuze posługuje się tym pojęciem z dziedziny meteorologii, żeby wyjaśnić, że różnice nie potrzebują tożsamości. „Mroczny zwiastun” jest różnicą różnic, która zapewnia łączność między seriami zanim ich elementy się ukonstytuowały. 
gdyby była przeszła, przyszła, a nie teraźniejsza. Tak samo dziadek widzi siebie jako już zmarłego (widzi swoje życie jako przeszłe) i jako osobę już ocalałą (o ile to, co trzeba uratować wydaje się w pewien sposób niezależne od stanów rzeczy). Ale są to znowu tylko podobieństwa, wymieniłem tu elementy złożonej teraźniejszości, która się rozciąga i wraca nad sobą.

W przeciwieństwie do nich Aion może tylko świecić się na horyzoncie, tam, gdzie czyste wydarzenie czeka na nas i gdzie nie możemy wskazać początku, przeszłości, przyszłości: wojna, która staje się światem i dziadek, który staje się dziećmi nie „istnieją”, nie mają nawet kruchego istnienia obrazów czy wspomnień, są już za nami jako enigma wstrząsu (ale wydarzenie, zrodzone ze wstrząsu, odróżnia się od niego jako chwili Chronosa: jest niestworzone, bezosobowe, wieczne...) i przed nami, jako zrealizowanie sensu, który się nam zawsze wymyka i zmusza nas do nieustannego zapytywania: Zapamiętajcie! - powtarza wygrażając laska nie wiem komu - nam? samolotom? światu?

\section{Bibliografia}

Deleuze G., Différence et répétition, Paris 1968.

Deleuze G., Logique du sens, Paris 1969.

Deleuze G., Różnica i powtórzenie, przeł. B. Banasiak i K. Matuszewski, Warszawa 1997.

Deleuze G., Foucault, przeł. M. Gusin, Wrocław 2004.

Kapuściński R., Lapidaria, Warszawa 2008.

Marcel G., Od sprzeciwu do wezwania, Warszawa 1965.

\section{Abstract \\ Aion and the Singularities of Event}

Deleuze speaks about specific time of the event, which he names - following the stoics - Aion. Time that is eternal, immovable, incorporeal; time that is in opposition to Chronos, in which everything takes place and is corporeal.

To understand this temporality, one can explain the concept of an event by asking about its place.

An event is contained neither in objects nor in meanings nor in subjects. It is close to what Kapuściński calls „teatrum”: simultaneously a subject and an object. 
These particular properties are the result of the makeup of an event, of the singularities which create an event as one transforms into another, causing a cloud of virtualities and becomings to emerge.

In the quotation from Kapuściński, the grandfather who foretells war to the children (after he has noticed the dots of planes in the sky) is those children to some extent: he projects his life onto them; the coming tragedy and the presence of children make him sensitive to "what needs to be saved in them", which is also „what needs to be saved in him."

This process of becoming, which here is a part of the „war" event (but in itself already constitutes an event) is not merely a subjective impression; as an event it seems to enjoy an existence of its own (expressed here with the impersonal "needs to be"), inseparable from the theatrum of circumstances or "states of being".

Sense emerges from circumstances, yet it seems to be outside time, unmoving, always both already gone and coming: Aion.

Key words: temporality, event, sense, becoming, singularities 